\title{
Do we need computer skills to use a computer? : evidence from Britain
}

Citation for published version (APA):

Borghans, L., \& ter Weel, B. J. (2002). Do we need computer skills to use a computer? : evidence from Britain. Researchcentrum voor Onderwijs en Arbeidsmarkt, Faculteit der Economische Wetenschappen. ROA Research Memoranda No. 4E https://doi.org/10.26481/umaror.200204E

Document status and date:

Published: 01/01/2002

DOI:

10.26481/umaror.200204E

Document Version:

Publisher's PDF, also known as Version of record

\section{Please check the document version of this publication:}

- A submitted manuscript is the version of the article upon submission and before peer-review. There can be important differences between the submitted version and the official published version of record.

People interested in the research are advised to contact the author for the final version of the publication, or visit the DOI to the publisher's website.

- The final author version and the galley proof are versions of the publication after peer review.

- The final published version features the final layout of the paper including the volume, issue and page numbers.

Link to publication

\footnotetext{
General rights rights.

- You may freely distribute the URL identifying the publication in the public portal. please follow below link for the End User Agreement:

www.umlib.nl/taverne-license

Take down policy

If you believe that this document breaches copyright please contact us at:

repository@maastrichtuniversity.nl

providing details and we will investigate your claim.
}

Copyright and moral rights for the publications made accessible in the public portal are retained by the authors and/or other copyright owners and it is a condition of accessing publications that users recognise and abide by the legal requirements associated with these

- Users may download and print one copy of any publication from the public portal for the purpose of private study or research.

- You may not further distribute the material or use it for any profit-making activity or commercial gain

If the publication is distributed under the terms of Article $25 \mathrm{fa}$ of the Dutch Copyright Act, indicated by the "Taverne" license above, 


\title{
Do We Need Computer Skills to Use a Computer? Evidence from Britain*
}

\author{
ROA-RM-2002/4E
}

Lex Borghans, Bas ter Weel

* We would like to thank Daron Acemoglu, Jim Allen, Josh Angrist, David Autor, Eli Berman, Allard Bruinshoofd, Francis Green, Hans Heijke, Hugo Hollanders, Larry Katz, Francis Kramarz, Alan Krueger, Victor Lavy, Jasper van Loo, Paul Miller, Richard Murnane, Steve Pischke, Arthur van Soest, Luc Soete and Bruce Weinberg and seminar participants at CentER, the Dutch Central Bank, the London School of Economics, and Maastricht University for helpful comments and suggestions on an earlier draft of this paper. In addition, we are grateful to Francis Green and Alan Felstead for providing us with the data and for their help in explaining some of the variables. Financial support from the Netherlands Organization for Scientific Research (NWO) is also gratefully acknowledged.

\section{Research Centre for Education and the Labour Market}

Faculty of Economics and Business Administration

Maastricht University

Maastricht, December 2002 
ISBN 90-5321-351-1

Sec02.212.doc 


\begin{abstract}
Using data from the 1997 Skills Survey of the Employed British Workforce, we examine the returns to computer skills in Britain. Many researchers, using information on computer use, have concluded that wage differentials between computer users and non-users might, among others, be due to differences in the embodiment of computer skills. Using unique information on the importance, level of sophistication and effectiveness of computer use, we show that computer skills do not yield significant labour market returns for most types of use. Examining the returns to computer skills at different levels of sophistication of use, yields estimates suggesting returns to computer skills at the highest level of sophistication of use only.
\end{abstract}




\section{Introduction}

Most of us recognize the frustration if the computer does on many occasions not seem to do what we want it to do. It is even more demoralizing if a fellow worker always seems to be able to correct our computer disability at such instances and tell us exactly where we went wrong and how to proceed. Such experiences suggest that one needs computer skills to use a computer, since one has to have some understanding of how to operate the computer to perform computerized job activities at work. An interesting way to look at this problem is to investigate whether computer skills are rewarded by the employer or, put differently, whether computer skills yield labour market returns. The present paper presents such an analysis.

Since Krueger's analysis (Krueger 1993), suggesting that computer users earn substantially higher wages than non-users because of their computer skills, the returns to computer skills have been of interest to many researchers and policy makers. One interpretation of these findings has been that returns to computer skills might explain a substantial part of these higher wages. ${ }^{1}$ In this paper, we examine the labour market value of computer skills by investigating its returns using information from the 1997 Skills Survey of the Employed British Workforce. These data contain unique information about the importance, level of sophistication and effectiveness of computer use.

At least two features of our analysis set it apart from previous studies.

\footnotetext{
${ }^{1}$ Other explanations have been that the higher wages are due to unobserved heterogeneity (DiNardo and Pischke 1997), that high-wage workers receive computers first because of advantages in other skills complementary to computer use (Levy and Murnane 1996), and that firms using computers pay higher wages (Chennells and Van Reenen 1997, Doms, Dunne and Troske 1997, Entorf and Kramarz 1997, and Entorf, Gollac and Kramarz, 1999). Autor, Katz and Krueger (1998) and Katz and Autor (1999) review this literature extensively.
} 
First, we explore direct measures of the importance, level of sophistication and effectiveness of computer use at the worker's job, which allows us to analyze in a direct way the computer skills needed to perform the job. Previous studies (e.g., Bell 1996, DiNardo and Pischke 1996, and Hamilton 1997) have used data containing only dummy variables for computer knowledge or computer ability as a rough proxy for computer skills. ${ }^{2}$ Furthermore, these studies were only able to explore data on computer skills without explicitly being able to relate these skills to jobs, which led to respondents having computer skills but not using a computer at work and, more remarkably, to respondents using a computer at work without possessing computer skills. Second, we estimate the importance and effectiveness of computer use within levels of sophistication of computer use. In this way, we distinguish between workers using computers for simple tasks, such as printing out an invoice, and workers using computers for sophisticated tasks, such as programming and developing software. Analyzing returns to computer skills at different levels of sophistication is important because it seems less likely that a worker using a computer to e-mail receives large returns to the ability to do so, while it seems more likely that a software engineer receives returns to the ability to develop new computer applications.

Although there is little doubt that computer users embody more computer skills than non-users, it is important to analyze whether workers use computers because they have computer skills or whether computer use leads to acquiring computer skills. In addition, given the level of sophistication of computer use, it is important whether computer skills yield labour market returns. Even if skills as such do not yield labour market returns, one would expect users to acquire skills just by experience and learning by do-

\footnotetext{
${ }^{2}$ See Section 2 for more details.
} 
ing. ${ }^{3}$ Hence, the main problem is that if computer use is more common among higher skilled workers, a spurious correlation between computer skills and wages might show up in the data. The other way around, the use of a computer might be a necessary condition to be paid for having computer skills.

Therefore, the strategy of analyzing the returns to computer skills is twofold. First, the returns to computer skills within different levels of sophistication are investigated. These estimates yield information about the returns to computer skills not by comparing computer users and non-users, but by comparing different workers using computers for similar purposes. Second, the question whether workers use computers because of their computer skills or whether they got computer skilled once they adopted a computer is analyzed by focusing on the returns to computer skills of those workers who use the computer for a while. In this way, spurious correlations between the relatively low computer skills of recent users and their selective characteristics are likely to be avoided.

A nice way to understand the strategy of the analysis in this paper, is the following: David Beckham has great football skills, but if he does not use those skills on the pitch it is doubtful whether these skills are well paid. ${ }^{4}$ In other words, our research strategy is based on the fact that not all football players have the same talent. A difference in earnings between Beckham and someone who does not play football does not show the value of football

\footnotetext{
${ }^{3}$ For example, a worker who never used e-mail is probably not able to use this computer application instantly. After a couple of days, or taken part in a course on how to operate the PC and the software, the worker is likely to be able to send and process e-mails effectively. However, it seems to be unlikely that the employer is going to pay this worker for having acquired the computer skills to operate the PC and the e-mail software.

${ }^{4}$ We would like to thank Alan Krueger for making this point.
} 
skills. However, the wage differential between Beckham and Andy Johnson (West Bromwich Albion) shows that football skills have a real market value. Other skills, such as knowledge about the Premier League's rules, will also be much more present among football players, but a correlation between the skill and wages within the group of players is not to be expected. In a similar fashion, we analyze differences in computer skills within the same level of sophistication of use (in football terms within the Premier League, within the First Division, etc.). In addition, similar to Beckham signing a huge contract with Manchester United, rather than with West Bromwich Albion, because of his scarce football skills, we analyze whether workers earn higher wages because of the use of their valuable computer skills or that computer skills do not yield labour market returns but are an unavoidable consequence of using a computer.

Our findings can be summarized as follows. Workers using computers at work earn substantially higher wages than non-users (21.4 percent). The more important computer use and the higher the level of sophistication, the higher the wage differential between computer users and non-users. However, these wage differentials cannot be explained by differences in the embodiment of computer skills among different workers. Investigating the returns to computer skills does not yield differences between workers who are always able to operate the computer effectively and workers only sometimes being able to use the computer effectively. Investigating the returns to computer skills for different levels of computer use also reveals that computer skills do not yield labour market returns. Only workers operating computers at the most advanced level - i.e., using a computer syntax and/or formulae for programming and developing software - receive a return on their computer skills. Finally, our estimates reveal that workers using a computer for a longer time 
are more effective than recent users, suggesting on-the-job learning by doing rather than large investments in computer skills.

This paper proceeds as follows. Section 2 presents the data and discusses issues concerning the measurement of computer skills. Section 3 presents the estimation results. Section 4 concludes.

\section{Data and Skill Measurement}

\section{$2.1 \quad$ Data}

The data used in this paper have been collected in a survey, conducted in the first half of 1997, called the Skills Survey of the Employed British Workforce. The survey includes a representative number of workers $(2,467)$ from Britain aged 18-60 (see the Data Appendix for descriptive statistics). Participants were asked several dozens of questions on their labour market situation during face-to-face interviews to obtain information on various aspects of their jobs including qualifications, responsibilities, the importance and ability to carry out certain tasks at work, and training. ${ }^{5}$

Of interest for the purpose of our analysis are the detailed questions concerning the importance, level of sophistication, and effectiveness of computer use. Particularly the information on the latter two is unique. With respect to the level of sophistication of computer use, Entorf and Kramarz (1997) and Entorf, Gollac and Kramarz (1999) use the Enquête sur la Technique et l'Organisation du Travail auprès des Travailleurs Occupés, in which they distinguish three levels of computer use related to the autonomy of each worker. This is an indirect measure of the level of sophistication of com-

\footnotetext{
${ }^{5}$ Ashton, Davies, Felstead and Green (1999) provide a detailed overview of the data, its collection, and the design of the questionnaire.
} 
puter use because it relates to the job in general, whereas the data used in this paper relate the level of sophistication of computer use to the worker's computerized tasks. The effectiveness of computer use has been measured indirectly as computer ability (Bell 1996) or computer knowledge (DiNardo and Pischke 1996, and Hamilton 1997). Bell uses data from the U.K. National Child Development Study and DiNardo and Pischke utilize data from the West German Qualification and Career Survey conducted by the Federal Institute for Vocational Training. In these data information on both computer use and computer knowledge is available. Hamilton uses variables from the 1986 High School and Beyond Survey indicating whether an individual has ever used software packages or a computer language to program. These measures are related to computer ability or skills in a general sense, but do not necessarily reveal information about the effectiveness of conducting computerized job activities. The information on the effectiveness of computer use from the data analyzed in this paper is directly related to the computerized tasks a worker has to perform. By measuring its effectiveness, a proxy for the worker's computer skills directly related to the job is obtained.

With regard to the importance of computer use the following question has been asked: "In your job, how important is using a computer, PC, or other types of computerized equipment?" The response scale offered is the following: "essential", "very important", "fairly important", "not very important", and "not at all important". 6

With respect to the level of sophistication of computer use the following question has been asked: "Which of the following best describes your use of computers or computerized equipment in your job?" The answers are divided

\footnotetext{
${ }^{6}$ The answer "not at all important" is reported if workers do not use a computer at work.
} 
into four different levels of sophistication at which computers are being occupied. "Simple" use indicates "straightforward use, e.g., using a computer for straightforward routine procedures such as printing out an invoice in a shop"; "moderate" use means "e.g., using a computer for word processing and/or spreadsheets or communicating with others by email"; "complex" use is defined as "e.g., using a computer for analyzing information of design, including use of computer-aided design or statistical analysis packages"; and, "advanced" use is described as "e.g., using a computer syntax and/or formulae for programming and developing software".

The effectiveness of computer use is measured by the answers to the following question: "When your job involves using a computer, PC or other type of computerized equipment, are you able to do this effectively?" Five possible answer categories were offered: "always", "nearly always", "often", "sometimes" and "hardly ever". 7

\subsection{Skill Measurement}

The question used to measure the effectiveness of computer use - to approximate computer skills - has been subject of substantial debate among economists, psychologists and sociologists, especially in the literature regarding the importance of language skills (e.g., Willis and Rosen 1979, Borjas 1994, Chiswick and Miller 1995, Berman, Lang and Siniver 2001, and Dustmann and Van Soest 2001). Surveys relying upon the respondent's selfassessment to acquire information about ability and skill often use a question like "how would you rate your current writing skills in English?". The

\footnotetext{
${ }^{7}$ Note that the design of the questions in the survey is such that questions on the level of sophistication and effectiveness of computer use have not been asked to people who indicate that they do not use a computer at work.
} 
response alternatives are "very good", "good", "fair", "poor", or "cannot write in English" Such answers, in the absence of independent verification (e.g., objective tests), question the reliability of the responses for reasons of social desirability and self-referencing, which encourage over-estimation of ability and skill and are likely to bias the data in unidentifiable ways. ${ }^{8}$

For academic abilities and skills such as reading, writing and mathematics, it is possible to measure a respondent's skills by test items. This has the obvious advantage that for all respondents the skills are measured in an identical way. While the OECD will use this approach for numeracy and literacy skills in the forthcoming Life Skills Survey, computer skills seem to be too much context- or task-related to allow for a general set of test items (see for example, OECD 2000 for a discussion).

Although the approach taken in the data used in this paper also relies upon the self-assessment of the respondent, the main strategy has been to assess and approximate skills through questions on several tasks a respondent has to carry out at work, rather than directly asking the respondent to evaluate the own skill level. The main reason to use this approach has been that being asked to describe whether one carries out the tasks at work effectively seems to be much less subject to self-esteem than being asked to assess one's own abilities. Furthermore, the questions are directly linked to the tasks that must be fulfilled, which is likely to directly influence the performance of the job and therefore the wage. Rather than collecting information about an abstract skill, the question is directly addressed to the success of using a computer, i.e. the question is competence-based. Finally, Spenner

\footnotetext{
${ }^{8}$ See Spenner (1990) for a discussion of these kinds of data problems and Bertrand and Mullainathan (2001) for a summary of the literature using such measures and the integration of data into a measurement-error framework as to understand what they imply for empirical research relying on subjective data.
} 
(1990) reports evidence from a number of studies finding high correlations between self-assessed measures of skill obtained by this and similar ways of questioning and measures obtained from objective judgements by experts and external expert systems used to develop the Dictionary of Occupational Titles. We empirically address the validity of the skill measure in Section 3.4 .

\subsection{Descriptives}

Table 1 reports the distribution of the answers to the three computer questions. Panel A reports information about the importance of computer use, Panel B and C report the distribution of answers of computer users on their level of sophistication and effectiveness of use. 69.2 percent of the sample population uses a computer at work, which is comparable to figures reported for Germany and the United States in the late 1990s (e.g., Borghans and Ter Weel 2002). The numbers reported in Panel A indicate that computer use is "essential" in almost one-third of all cases, and in 14.7 percent it is regarded as "very important"; 11.5 percent of the respondents reported that computer use is "not very important".

The level of sophistication of computer use, reported in Panel B, is skewed towards "simple" and "moderate" tasks like routine procedures, such as printing out an invoice in a shop and using a computer for word processing and/or spreadsheets or communicating with others by email. Only 3.4 percent of the respondents uses the computer at the "advanced" level, i.e. using a computer syntax and/or formulae for programming and developing software.

The figures reported in Panel C show that more than half of the workers in the sample are relatively well able to use the computer effectively ("always" 
and "nearly always"). Among those who use a computer, there seems to be a relatively large portion who are often not able to carry out the computerized part of the job effectively: 10.2 percent of the total sample population answers "sometimes" or "hardly ever" being able to use computers effectively.

\section{TABLE 1 OVER HERE}

Table 2 reports the frequencies of the effectiveness of computer use within different levels of importance of computer use (Panel A) and within different levels of sophistication of computer use (Panel B). Panel A communicates information on the effectiveness of computer use for different levels of importance of use. The frequencies in this panel show that workers in jobs in which a computer is more important seem to be more able to perform computerized tasks effectively. In a similar way, Panel B provides information on the effectiveness of use for workers who use the computer at different levels of sophistication. Again higher levels of sophistication seem to go along with higher levels of effectiveness of use. These numbers reveal that the questions on computer use have been answered consistently and in line with the a priori expectation that workers being relatively effective in using a computer, use it for more important tasks and operate it at a higher level of sophistication.

\section{TABLE 2 OVER HERE}




\section{Computer Use and Wages}

\subsection{Basic Estimates}

To examine the returns to the importance, level of sophistication and effectiveness of computer use, we first run some standard (OLS) wage regressions and augment the standard cross-sectional wage equation by including a dummy variable for computer use. The wage equation then looks like $\ln W_{i}=D+\alpha X_{i}+\beta C_{i}+\epsilon_{i}$, where $\ln W_{i}$ is the log of the gross hourly wage, $X_{i}$ is a vector of observed characteristics. and $C_{i}$ represents a dummy variable that equals 1 if worker $i$ uses a computer at work, and 0 otherwise; $\alpha$ and $\beta$ are the estimated parameters, $D$ is a constant, and $\epsilon_{i}$ is an error term with the usual assumptions.

Column (1) of Table 3 reports the results of estimating this equation. Besides the dummy variable for computer use the regression equation includes the usual labour market variables, such as educational level (ranging from a university degree to the NVQ1 level, where workers without a degree are the reference group), experience and experience squared, and occupational and sector dummies, and the following unreported variables: gender, being married, married $\times$ gender, being a union member and being a supervisor. The equation also includes an unreported intercept. ${ }^{9}$ The size of the dummy vari-

\footnotetext{
${ }^{9}$ We also investigated equations including information about tenure, whether the job a worker occupies is temporary or permanent, the number of hours worked and the number of hours worked squared. Although all estimates on these variables are significant at the 5 percent level, they do not change the overall picture shown in Table 3. We have also ran regressions for men and women separately. Again the magnitude of the results does not change significantly; in a similar regression as the one reported in column (1), the coefficient (standard error in brackets) for men equals .197 (.037) and for women .173 (.032). The results of taking into account the importance, level of sophistication and effectiveness of
} 
able for computer use equals 21.4 percent (exp(.194)-1), which is consistent with the findings of others. ${ }^{10}$ The regression results reported in column (2) show estimates for the effects of the importance of computer use on wages. The coefficients reveal that, relative to a worker not using a computer, the returns to computer use are higher the higher the importance of computer use. The same conclusion can be drawn from the estimates presented in column (3): the level of sophistication of computer use exerts a positive impact on the wages of computer users relative to non-users.

Finally, column (4) reports the coefficients if including the effectiveness of computer use into the regression equation. The coefficients still suggest a substantial wage differential between computer users and non-users but the coefficients for the effectiveness of computer use at the four highest levels do not significantly differ from each other. Only workers reporting to be "hardly ever" able to use the computer effectively do not earn significantly higher wages than non-users, although the point estimate is quite large and significant at the 10 percent level suggesting that workers who are hardly ever able to use a computer effectively earn almost 10 percent higher wages than similar workers who do not use a computer.

The results from estimating these four straightforward wage equations, putting forward the returns to different aspects of computer use, are interesting. The positive correlation between the level of sophistication of use and wages in Table 3 and the positive relation between the level of sophisticacomputer use (as shown in the other columns of Table 3) are also comparable if we include additional variables and run separate regressions for male and female workers.

${ }^{10}$ See e.g., Krueger (1993) for the United States and DiNardo and Pischke (1996) for Germany. Only including the dummy variable for computer use and an intercept leads to an estimated wage differential between workers who use computers and workers who do not of 57.6 percent. 
tion and effectiveness of computer use in Table 2 would lead one to predict a positive correlation between the effectiveness of computer use and wages too. The same argument applies to the importance of computer use, because if computer use is reported to be relatively important, workers are relatively effective in using the computer. However, this effect is not reflected in the returns to the effectiveness of computer use. This latter result would lead to the conclusion that the ability to use a computer does not matter for the wage, and that the wage differential between computer users and non-users cannot be attributed to differences in computer skills.

\section{TABLE 3 OVER HERE}

\subsection{Sophistication and Effectiveness}

To draw inferences about the returns to computer skills, we separate the higher wages computer users receive from the effectiveness of their computer use. To do so, we estimate returns to the effectiveness of computer use within each of the four levels of sophistication of computer use. In this way, we distinguish the programmer and software engineer, using a computer syntax and/or formulae for programming and developing software, from the secretary, using the computer for e-mailing and word processing. Since the importance and the level of sophistication of computer use are correlated with the effectiveness of computer use, the coefficients on the effectiveness might interfere with the relationship between computer use as such and wages. We therefore choose a specification for this wage equation as flexible as possible.

We estimate three different models. The first model includes the sixteen possible combinations of the importance of computer use (essential, very important, fairly important, and not very important) and the level of so- 
phistication of computer use (advanced, complex, moderate, and simple). Workers not using a computer at work are used as the reference group. The second model includes twenty combinations of the effectiveness of computer use (always, nearly always, often, sometimes and hardly ever) and the level of sophistication. Again those workers not using computers are taken as the reference group. Finally, we estimate a model including sixteen dummy variables in which we combine the importance and effectiveness of computer use (important and effective, important and ineffective, unimportant and effective, and unimportant and ineffective) with the level of sophistication, using non-users as the reference group.

When constructing the variables it turns out that there are no computer users reporting their computer use as fairly important and not very important at the advanced level of sophistication. In addition, at the complex level of sophistication, no computer user regards his computer use as not very important. For the effectiveness of computer use it turns out that within the advanced level of computer use only workers are present reporting their computer use to be always and nearly always effective. Similarly, at the complex level of computer use there are no workers reporting that they are hardly ever able to use the computer effectively. For the combination of importance and effectiveness we only have observations within the advanced level of sophistication when computer use is both important and effective.

Table 4 reports the estimates from estimating these wage equations. Panel A includes the importance of computer use for each level of sophistication, Panel B the effectiveness of computer use, and Panel C a composite measure of the importance and effectiveness of computer use.

The estimates reported in Panel A of Table 4 suggest that at the advanced level of sophistication of computer use the workers for which computer use 
is essential gain most (in terms of wages) from computer use. Although the point estimate is higher, the coefficient cannot be statistically distinguished from the coefficient for workers reporting that computer use is very important. For workers using the computer at the complex level of sophistication a similar effect is obtained, although the coefficient for workers whose computer use is only fairly important is comparable. Going down the level of sophistication of computer use further, reveals similar patterns. Hence, controlling for the level of sophistication shows that the effects of the importance of computer use on wages is rather limited. Although the point estimates suggest a higher wage if computer use is more important, it is in most instances not possible to statistically discriminate between the coefficients within each level of sophistication.

Panel B of Table 4 presents a similar analysis of the effectiveness of computer use. For the advanced level of sophistication of computer use, workers whose effectiveness in using the computer is highest receive the highest wages. This result is not surprising given the occupations for which advanced computer use is required. These are mostly workers using the computer as their main job activity, such as programming and developing software etc. Hence, being effective in using the computer leads to higher productivity and wages. If the computer is used for complex tasks, the level of effectiveness of use does not seem to be of main importance. Workers reporting being often able to use the computer effectively gain most from computer use. For moderate and simple levels of sophistication of computer use, workers reporting being sometimes able to use the computer effectively benefit to the largest extent, although the coefficients are not significantly different from higher levels of effectiveness. Looking at the rather flat pattern of regression coefficients from Table 3, these hump-shaped patterns are to be expected because there is a 
positive relationship between the level of sophistication of computer use and wages and between the sophistication of use and the effectiveness of computer use (Table 2). Therefore, a flat pattern for the overall relationship between computer skills and wages can only exist if within some levels of sophistication more skills are associated with lower wages.

The results presented in Panel A and B could be shaped by the interaction between the importance of computer use and its effectiveness. We therefore control for the possibility of interaction effects. Since the number of possible interaction effects is too large, we constructed four composite measures. First, computer use might be both important and effective. This is defined as workers reporting essential or very important with respect to the importance of computer use and answering always and nearly always if asked about their effectiveness of computer use. Second, computer use might be important and ineffective. Ineffectiveness is defined as workers responding often, sometimes or hardly ever on the question about the effectiveness of computer use. Third, computer use might be unimportant and effective. Unimportance is defined as workers reporting their computer use to be fairly important or not very important. Fourth, computer use might be unimportant and ineffective.

Panel $\mathrm{C}$ of Table 4 reports the effects of the four composite measures on wages within each level of sophistication of computer use. The results are consistent with the estimates reported in Panel A and B. If using a computer is relatively important, the wage gain is highest. For the estimates it does not seem to matter very much whether the use of the computer is effective or not. Hence, the importance of computer use explains the higher wages of computer users better than the effectiveness of computer use, which is consistent with the estimates reported in Table 3 and runs counter to the perception of those propagating the importance of computer skills for labour 
market success.

\section{TABLE 4 OVER HERE}

\subsection{Experience with Using Computers}

The only regression coefficient in Table 3 that suggests positive returns to computer skills is the significantly lower wage premium for the computer users with the lowest effectiveness of computer use. The reason for this pattern might be that many of those who report a low effectiveness of computer use started to use the computer only recently. The wages are therefore likely to reflect the selective characteristics of this newly group of computer users rather than a penalty for low skills as such.

We are able to analyze this because the data include information on the use of computers five years prior to the survey (i.e., in 1992). If we exclude those workers who did not use a computer five years ago, the regression coefficients of a regression similar to the one reported in column (4) of Table 3 are the following (standard errors in parentheses): .312 (.067), .323 (.068), .315 (.082), .298 (.089), and .308 (.135), respectively. Particularly the coefficient for the least computer skilled workers has gone up dramatically, which means that there are no differences in the returns between the skill levels. Excluding recent users from the extended analysis reported in Table 4, has similar effects: The wage premium for the lowest level of effectiveness becomes similar to the premiums for higher skill levels and within each level of sophistication computer skills are only rewarded at the highest level of sophistication. These estimates suggest that workers who use a computer for a longer time receive the same wage premium, regardless of their computer skills. This implies that differences in computer skills between workers do 
not explain differences in wages.

Our interpretation of these coefficients is that recent users are least effective in using computers. Their lower wages are however not caused by this lack of computer skills but origin from other sources.

\subsection{Validity of the Skill Measure}

A concern about the regression results is whether the information used for the effectiveness of computer use is measured adequately. If the measure would be poor, a lack of significant results from the regressions reported in Tables 3 and 4 could demonstrate the low quality of the measure rather than a lack of returns to the effectiveness of computer use at work. Although subjective measurement will always suffer to some extent from limited self-knowledge and possible exaggerations of a worker's ability and skill level, the measure is likely to be adequate for the following three reasons.

First, comparing the estimation results of the effectiveness of computer use with other measures from the same survey, yields estimates in line with a priori expectations. In particular, workers grade themselves lower with regard to skills and tasks viewed upon as relatively difficult, such as analytical thinking and carrying out complex and mathematical problems.

Second, the positive relation between the importance, level of sophistication and effectiveness of computer use reported in Table 2 rejects the suspicion that the self-assessed computer skill measure is biased.

Finally, Table 5 reports regression results for effectiveness questions on five other job items using the same subjective measure and performed using the same controls as the regression in column (4) of Table 3. The questions whether a worker is able to perform certain job activities effectively have been asked for the following job items: 1 . analyzing complex problems; 2 . helping 
other team members; 3. making speeches or presentations; 4. writing short documents with correct spelling and grammar (for example, short reports, letters or memos); and 5. reading and understanding short documents such as short reports, letters or memos. The estimates reported in Table 5 suggest that, unlike the estimates for effectiveness of computer use, higher levels of effectiveness yield higher returns.

\section{TABLE 5 OVER HERE}

\section{Conclusion}

The main goal of this paper has been to investigate the labour market returns to computer skills using unique and detailed information on the importance, level of sophistication and effectiveness of computer use at work. The results from the empirical analysis presented in this paper confirm previous findings that computer users earn higher wages than non-users but adds to this that the effectiveness of computer use, used to approximate computer skills, does not yield labour market returns. Analyzing the returns to computer skills for different levels of sophistication of computer use yields estimates suggesting returns to computer skills at the advanced level of sophistication of use only.

Our reading of these results is the following. First, differences in computer skills between workers do not explain why workers using a computer earn higher wages than non-users. There are only returns to computer skills if the computer is used in an advanced manner. This suggests that the computerized job activities are of central importance only if the computer is occupied at the advanced level. In most instances the computer is likely to be used for routine job activities, which are not particularly the motivation for 
hiring a worker and, as a result, the worker is not paid for the performance of these activities. This is consistent with casual observations, since most workers use the computer for secondary tasks - such as typing a manuscript, sending e-mails, and running regressions - only.

Second, a large part of the size of the coefficients reported in column (2) and (3) in Table 3 is due to computer use as such. It is beyond the scope of the present paper to go into the reasons why computer users earn higher wages than non-users, but the estimates in Entorf and Kamarz (1997) and Entorf, Gollac and Kramarz (1999) and Chennells and Van Reenen (1997) suggest that computer users were already earning higher wages than non-users before using computers. This is consistent with the view that employers utilize computers first in high-wage jobs to save on relatively expensive labour and explains why higher educated and more experienced workers use computers. It is also consistent with our results, because we have shown that the recent computer users earn lower wages than workers already using computers for a longer period of time, which could be interpreted as those workers getting computers later because of their lower wages.

Third, the regression results suggest that the effectiveness of computer use is a matter of learning by doing: Computer skills do not yield labour market returns but workers using the computer for a longer period of time are more effective in using it. This insight also leads to the conclusion that large investments in computer skills and intensive educational programs to teach pupils how to use computers are unlikely to be effective. Most computer skills are likely to be acquired by experience and rather easily learned when necessary at work.

Hence, our fellow worker - who is always able to show us how to use the computer effectively and to correct our mistakes - is obviously more 
computer skilled than we are, but does not receive a higher wage because of this superior effectiveness.

\section{References}

Ashton, David, Bryn Davies, Alan Felstead and Francis Green (1999), "Work Skills in Britain," ESRC Centre on Skills Knowledge and Organisational Performance (SKOPE), Oxford and Warwick Universities.

Autor, David H., Lawrence F. Katz and Alan B. Krueger (1998), "Computing Inequality: Have Computers Changed the Labor Market?," Quarterly Journal of Economics, vol. 113, pp. 1169-1213.

Bell, Brian D. (1996), "Skill-Biased Technical Change and Wages: Evidence from a Longitudinal Data Set," Nuffield College, Mimeo, July 1996.

Berman, Eli, Kevin Lang and Erez Siniver (2001), "Language Skill Complementarity: Returns to Immigrant Language Acquisition," Boston University, Mimeo, June 2001.

Bertrand, Marianne and Sendhil Mullainathan (2001), "Do People Mean What They Say? Implications for Subjective Survey Data," American Economic Review, vol. 91, Papers and Proceedings, pp. 67-72.

Borghans, Lex and Bas ter Weel (2002), "Do Older Workers Have More Trouble Using a Computer than Younger Workers?" Research in Labor Economics, vol. 21, pp. 139-173.

Borjas, George J. (1994), "Self-Selection and the Earnings of Immigrants," American Economic Review, vol. 77, pp. 531-553.

Chiswick, Barry R. and Paul W. Miller (1995), "The Endogeneity between Language and Earnings: International Analyses," Journal of Labor Economics, vol. 13, pp. 246-288. 
Chennells, Lucy and John Van Reenen (1997), "Technical Change and Earnings in British Establishments," Economica, vol. 64, pp. 587-604.

DiNardo, John and Jörn-Steffen Pischke (1996), "The Return to Computer Use Revisited: Have Pencils Changed the Wage Structure too?," NBER Working Paper 5606, June 1996.

DiNardo, John and Jörn-Steffen Pischke (1997), "The Return to Computer Use Revisited: Have Pencils Changed the Wage Structure too?," Quarterly Journal of Economics, vol. 112, pp. 291-303.

Doms, Mark, Timothy Dunne and Kenneth R. Troske (1997), "Workers, Wages and Technology," Quarterly Journal of Economics, vol. 112, pp. 253290.

Dustmann, Christian and Arthur van Soest (2001), "Language Fluency and Earnings: Estimation with Misclassified Language Indicators," Review of Economics and Statistics, vol. 83, pp. 663-674.

Entorf, Horst, Michel Gollac and Francis Kramarz (1999), "New Technologies, Wages and Worker Selection," Journal of Labor Economics, vol. 17, pp. 464-491.

Entorf, Horst and Francis Kramarz (1997), "Does Unmeasured Ability Explain the Higher Wages of New Technology Workers?," European Economic Review, vol. 41, pp. 1489-1509.

Hamilton, Barton H. (1997), "Returns to Computer Skills and BlackWhite Wage Differentials," John M. Olin School of Business, Mimeo, March 1997.

Katz, Lawrence F. and David H. Autor (1999), "Changes in the Wage Structure and Earnings Inequality," in Handbook of Labor Economics, vol. 3, Orley Ashenfelter and David H. Card, eds. (North-Holland: Amsterdam), pp. $1463-1555$. 
Krueger, Alan B. (1993), "How Computers Have Changed the Wage Structure: Evidence from Microdata, 1984-1989," Quarterly Journal of Economics, vol. 108, pp. 33-60.

Levy, Frank and Richard J. Murnane (1996), "With What Skills Are Computers Complements?," American Economic Review, vol. 86, Papers and Proceedings, pp. 258-262.

OECD (2000), "Adult Literacy and Life Skills: Computer Literacy," OECD, Mimeo, November 2000.

Spenner, Kenneth I. (1990), "Skill: Meaning, Methods and Measures," Work and Occupations, vol. 17, pp. 399-421.

Willis, Robert J. and Sherwin Rosen (1979), "Education and Self-Selection," Journal of Political Economy, vol. 87, pp. 517-536. 


\section{Data Appendix}

Descriptive Statistics

\begin{tabular}{|c|c|c|c|}
\hline \multicolumn{2}{|l|}{ Variable } & $\begin{array}{l}\text { Percentage } \\
\text { in survey }\end{array}$ & $\begin{array}{l}\text { Percentage } \\
\text { computer } \\
\text { use }\end{array}$ \\
\hline \multicolumn{2}{|l|}{ Male } & 52.9 & 69.2 \\
\hline \multicolumn{2}{|l|}{ Female } & 47.1 & 69.1 \\
\hline \multirow[t]{4}{*}{ Age } & $20-29$ & 20.9 & 67.8 \\
\hline & $30-39$ & 33.5 & 71.6 \\
\hline & $40-49$ & 26.1 & 71.9 \\
\hline & $50-60$ & 19.5 & 63.0 \\
\hline \multirow[t]{6}{*}{ Education } & University qualification & 9.9 & 95.5 \\
\hline & Professional qualification & 12.4 & 88.9 \\
\hline & NVQ3 qualification & 15.2 & 75.1 \\
\hline & NVQ2 qualification & 34.5 & 71.6 \\
\hline & NVQ1 qualification & 8.8 & 55.1 \\
\hline & No degree qualification & 19.3 & 40.2 \\
\hline \multicolumn{2}{|c|}{ Married men } & 37.4 & 70.5 \\
\hline \multicolumn{2}{|c|}{ Married women } & 31.9 & 67.0 \\
\hline \multicolumn{2}{|c|}{ Union coverage } & 48.4 & 76.9 \\
\hline \multicolumn{2}{|c|}{ Union member } & 32.5 & 76.4 \\
\hline \multicolumn{2}{|c|}{ Full-time workers } & 74.7 & 74.6 \\
\hline \multicolumn{2}{|c|}{ Permanent job } & 82.4 & 72.2 \\
\hline \multicolumn{2}{|c|}{ Self-employed } & 11.1 & 48.5 \\
\hline \multicolumn{4}{|c|}{ Occupations } \\
\hline \multicolumn{2}{|c|}{ Managers and Administrators } & 14.6 & 83.7 \\
\hline \multicolumn{2}{|c|}{ Professionals } & 10.5 & 93.8 \\
\hline \multicolumn{2}{|c|}{ Associate Professionals } & 10.4 & 86.4 \\
\hline \multicolumn{2}{|c|}{ Clerical and Secretarial } & 16.5 & 95.8 \\
\hline \multicolumn{2}{|c|}{ Craft and Related } & 12.2 & 55.3 \\
\hline \multicolumn{2}{|c|}{ Personal and Protective Services } & 10.5 & 45.2 \\
\hline \multicolumn{2}{|c|}{ Sales } & 7.1 & 68.8 \\
\hline \multicolumn{2}{|c|}{ Plant and Machine Operatives } & 10.7 & 42.8 \\
\hline \multicolumn{2}{|l|}{ Other } & 7.5 & 17.9 \\
\hline
\end{tabular}


Sectors

Agriculture, forestry and fishing

Energy and water supply

Extraction of minerals ${ }^{\text {a }}$

Metal goods, engineering and vehicle industries

Other manufacturing industries

Note: All data are taken from the Skills Survey of the Employed British Workforce. The occupational categories are based on the SOC and the classification of sectors on the SIC.

${ }^{a}$ The full name of this sector is Extraction of minerals other than fuels, manufacture of metals, mineral goods and chemicals. 
Table 1

Distribution of the answers to the questions about the importance, level of sophistication and effectiveness of computer use

Panel A Importance: "In your job, how important is using a computer, PC, or other types of computerized equipment?"

\begin{tabular}{llc}
\hline & & percentage \\
\hline 1. & Essential & 30.3 \\
2. & Very important & 14.7 \\
3. & Fairly important & 12.7 \\
4. & Not very important & 11.5 \\
5. & No computer use & 30.8 \\
\hline
\end{tabular}

Panel B Sophistication: "Which of the following best describes your use of computers or computerized equipment in your job?"

\begin{tabular}{llr}
\hline & & percentage \\
\hline 1. & Advanced & 3.4 \\
2. & Complex & 12.1 \\
3. & Moderate & 26.1 \\
4. & Simple & 27.6 \\
5. & No computer use & 30.8 \\
\hline
\end{tabular}

Panel C Effectiveness: "When your job involves using a computer, PC or other type of computerized equipment, are you able to do this effectively?"

\begin{tabular}{llr}
\hline & & percentage \\
\hline 1. & Always & 27.0 \\
2. & Nearly always & 24.8 \\
3. & Often & 7.2 \\
4. & Sometimes & 5.7 \\
5. & Hardly ever & 4.5 \\
6. & No computer use & 30.8 \\
\hline
\end{tabular}

Note: All data are taken from the 1997 Skills Survey of the Employed British Workforce. 
Table 2

Frequencies of the importance, level of sophistication and effectiveness of computer use

Panel A: Frequencies of effectiveness within different levels of importance use

\begin{tabular}{lrcrrr}
\hline & Always & Nearly always & Often & Sometimes & Hardly ever \\
\cline { 2 - 6 } Essential & 59.2 & 34.4 & 3.6 & 2.3 & .5 \\
$\begin{array}{l}\text { Very } \\
\text { important }\end{array}$ & 32.8 & 49.6 & 10.2 & 4.7 & 2.5 \\
$\begin{array}{l}\text { Fairly } \\
\text { important }\end{array}$ & 22.7 & 35.5 & 20.4 & 15.7 & 5.4 \\
$\begin{array}{l}\text { Not very } \\
\text { important }\end{array}$ & 12.0 & 22.6 & 17.3 & 20.1 & 27.2 \\
\hline
\end{tabular}

Panel B: Frequencies of effectiveness within different levels of sophistication of use

\begin{tabular}{lrcrrr}
\hline & Always & Nearly always & Often & Sometimes & Hardly ever \\
\cline { 2 - 6 } Advanced & 83.3 & 15.5 & 1.2 & - & - \\
Complex & 56.9 & 35.5 & 4.7 & 2.3 & .7 \\
Moderate & 38.3 & 45.0 & 11.2 & 4.5 & .9 \\
Simple & 27.5 & 30.9 & 13.8 & 15.7 & 11.6 \\
& & & & & \\
\hline
\end{tabular}

Note: All data are taken from the 1997 Skills Survey of the Employed British Workforce. - indicates no observations. Columns define the level of effectiveness of computer use ranging from "always" to "hardly ever". The rows in Panel A define the importance of computer use (ranging from "essential" to "not very important"). The rows in Panel B define the level of sophistication of computer use (ranging from "advanced" to "simple"). The rows in the table add up to 100 percent. The definitions of the importance, level of sophistication and effectiveness of computer use are reported in the text and its distributions are shown in Table 1. 
Table 3

Estimates of the effect of computers on pay (dependent variable: ln (hourly wage))

\begin{tabular}{|c|c|c|c|c|}
\hline & 1 & 2 & 3 & 4 \\
\hline \multicolumn{5}{|l|}{ Educational level } \\
\hline 1. University & $.390(.044)^{*}$ & $.367(.044)^{*}$ & $.343(.044)^{*}$ & $.382(.044)^{*}$ \\
\hline qualification & $.249(.040)^{*}$ & $.244(.040)^{*}$ & $.228(.040)^{*}$ & $.244(.040)^{*}$ \\
\hline 2. Professional & $.162(.034)^{*}$ & $.150(.034)^{*}$ & $.142(.034)^{*}$ & $.159(.035)^{*}$ \\
\hline qualification & $.131(.029)^{*}$ & $.126(.029)^{*}$ & $.121(.029)^{*}$ & $.128(.029)^{*}$ \\
\hline 3. NVQ3 qualification & $.047(.040)$ & $.042(.040)$ & $.045(.039)$ & $.042(.040)$ \\
\hline \multicolumn{5}{|l|}{ 4. NVQ2 qualification } \\
\hline \multicolumn{5}{|l|}{ 5. NVQ1 qualification } \\
\hline Experience & $.010(.004)^{*}$ & $.010(.004)^{*}$ & $.010(.004)^{*}$ & $.010(.004)^{*}$ \\
\hline Experience squared & $-.001(.000)^{*}$ & $-.001(.000)^{*}$ & $-.001(.000)^{*}$ & $-.001(.000)^{*}$ \\
\hline Dummy for computer use & $.194(.025)^{*}$ & & & \\
\hline \multicolumn{5}{|l|}{ Importance } \\
\hline 1. Essential & & $.293(.030)^{*}$ & & \\
\hline 2. Very important & & $.212(.033)^{*}$ & & \\
\hline 3. Fairly important & & $.137(.034)^{*}$ & & \\
\hline 4. Not very important & & $.115(.034)^{*}$ & & \\
\hline \multicolumn{5}{|l|}{ Sophistication } \\
\hline 1. Advanced & & & $.386(.057)^{*}$ & \\
\hline 2. Complex & & & $.296(.036)^{*}$ & \\
\hline 3. Moderate & & & $.256(.030)^{*}$ & \\
\hline 4. Simple & & & $.115(.027)^{*}$ & \\
\hline \multicolumn{5}{|l|}{ Effectiveness } \\
\hline 1. Always & & & & $.206(.030)^{*}$ \\
\hline 2. Nearly Always & & & & $.209(.030)^{*}$ \\
\hline 3. Often & & & & $.224(.041)^{*}$ \\
\hline 4. Sometimes & & & & $.200(.045)^{*}$ \\
\hline 5. Hardly Ever & & & & $.082(.049)$ \\
\hline Occupational dummies & Yes & Yes & Yes & Yes \\
\hline Sector dummies & Yes & Yes & Yes & Yes \\
\hline Adjusted $\mathrm{R}^{2}$ & .395 & .405 & .406 & .395 \\
\hline
\end{tabular}

Note: All data are taken from the Skills Survey of the Employed British Workforce. All regressions are performed by OLS (standard errors are in parentheses). * is significant at the 5 percent level. All regressions also include an unreported intercept and control for gender, being married, married $\times$ gender, being a union member and being a supervisor. Educational levels are classified in five categories, which correspond to the U.K. classifications (workers without a qualification are used as the reference group). Occupations and sectors are listed in the appendix. 
Estimates of the relationship between the importance and effectiveness of computer use within levels of sophistication of use (dependent variable: ln (hourly wage))

Panel A: Returns to importance of computer use within different levels of sophistication

Level of sophistication of computer use

\begin{tabular}{lllll}
\hline Importance & \multicolumn{1}{c}{ Advanced } & Complex & Moderate & Simple \\
\cline { 2 - 5 } 1. Essential & $.392(.059)^{*}$ & $.312(.040)^{*}$ & $.334(.036)^{*}$ & $.161(.044)^{*}$ \\
2. Very important & $.351(.179)$ & $.274(.062)^{*}$ & $.281(.044)^{*}$ & $.107(.045)^{*}$ \\
3. Fairly important & - & $.311(.109)^{*}$ & $.122(.047)^{*}$ & $.135(.043)^{*}$ \\
4. Not very important & - & - & $.147(.079)$ & $.092(.037)^{*}$ \\
\hline
\end{tabular}

Panel B: Returns to effectiveness of computer use within different levels of sophistication

\begin{tabular}{lllll} 
Effectiveness & \multicolumn{1}{c}{ Advanced } & Complex & Moderate & Simple \\
\cline { 2 - 5 } 1. Always & $.418(.061)^{*}$ & $.279(.043)^{*}$ & $.222(.039)^{*}$ & $.081(.041)$ \\
2. Nearly always & $.235(.124)$ & $.290(.051)^{*}$ & $.272(.036)^{*}$ & $.124(.039)^{*}$ \\
3. Often & - & $.536(.120)^{*}$ & $.296(.060)^{*}$ & $.141(.053)^{*}$ \\
4. Sometimes & - & $.350(.167)^{*}$ & $.316(.092)^{*}$ & $.165(.050)^{*}$ \\
5. Hardly ever & - & - & $.003(.197)$ & $.054(.058)$ \\
\hline
\end{tabular}

Panel C: Returns to importance and effectiveness within different levels of sophistication

\begin{tabular}{lllll}
\hline Importance \& effectiveness & \multicolumn{1}{c}{ Advanced } & Complex & Moderate & Simple \\
\cline { 2 - 5 } & $.389(.057)^{*}$ & $.290(.038)^{*}$ & $.298(.033)^{*}$ & $.138(.037)^{*}$ \\
1. Important \& effective & - & $.433(.111)^{*}$ & $.453(.079)^{*}$ & $.092(.067)$ \\
2. Important \& ineffective & - & $.274(.119)^{*}$ & $.090(.051)$ & $.065(.044)$ \\
3. Unimportant \& effective & - & $.424(.157)^{*}$ & $.184(.062)^{*}$ & $.135(.037)^{*}$ \\
4. Unimportant \& ineffective & - & &
\end{tabular}

Note: All data are taken from the Skills Survey of the Employed British Workforce. All regressions are performed by OLS (standard errors are in parentheses) and include the same controls as the regressions reported in Table 3. * is significant at the 5 percent level. - indicates no observations. Panel A reports estimates for the importance of computer use for all four level of sophistication of computer use separately. Panel B reports estimates for the effectiveness of computer use for all four levels of sophistication of computer use separately. Panel C reports similar estimates on the following four constructed variables for importance and effectiveness: 1 . The importance of computer use is "essential" or "very important" and the effectiveness of use is "always" or "nearly always"; 2. The importance of computer use is "essential" or "very important" and the effectiveness of use is "often", "sometimes" or "hardly ever"; 3 . The importance of computer use is "fairly important" or "not very important" and the effectiveness of use is "always" or "nearly always"; and 4. The importance of computer use is "fairly important" or "not very important" and the effectiveness of use is "often", "sometimes" or "hardly ever". 
Table 5

Robustness of the skill measure (dependent variable: ln (hourly wage))

\begin{tabular}{|c|c|c|}
\hline Skill measure & & Return \\
\hline \multirow[t]{5}{*}{ Analyzing complex problems } & 1. Always & $.165(.033)^{*}$ \\
\hline & 2. Nearly always & $.145(.029)^{*}$ \\
\hline & 3. Often & $.123(.036)^{*}$ \\
\hline & 4. Sometimes & $.064(.024)^{*}$ \\
\hline & 5. Hardly ever & $.052(.052)$ \\
\hline \multirow[t]{5}{*}{ Helping other team members } & 1. Always & $.150(.039)^{*}$ \\
\hline & 2. Nearly always & $.193(.039)^{*}$ \\
\hline & 3. Often & $.191(.047)^{*}$ \\
\hline & 4. Sometimes & $.096(.043)^{*}$ \\
\hline & 5. Hardly ever & $.066(.111)$ \\
\hline \multirow[t]{5}{*}{ Making speeches or presentations } & 1. Always & $.198(.037)^{*}$ \\
\hline & 2. Nearly always & $.169(.030)^{*}$ \\
\hline & 3. Often & $.174(.036)^{*}$ \\
\hline & 4. Sometimes & $.097(.037)^{*}$ \\
\hline & 5. Hardly ever & $.072(.036)$ \\
\hline \multirow[t]{5}{*}{ Writing short documents with correct } & 1. Always & $.172(.030)^{*}$ \\
\hline & 2. Nearly always & $.164(.030)^{*}$ \\
\hline & 3. Often & $.096(.043)^{*}$ \\
\hline & 4. Sometimes & $.062(.044)$ \\
\hline & 5. Hardly ever & $.065(.047)$ \\
\hline \multirow[t]{5}{*}{ Reading and understanding } & 1. Always & $.149(.035)^{*}$ \\
\hline & 2. Nearly always & $.167(.035)^{*}$ \\
\hline & 3. Often & $.129(.050)^{*}$ \\
\hline & 4. Sometimes & $.034(.048)$ \\
\hline & 5. Hardly ever & $.011(.047)$ \\
\hline
\end{tabular}

Note: All data are taken from the Skills Survey of the Employed British Workforce. All regressions are performed by OLS (standard errors are in parentheses). * is significant at the 5 percent level. The regressions are similar to the one reported in Table 3, column (4) and include the same controls. The adjusted $\mathrm{R}^{2}$ 's are $.378, .376, .382$, .380 , and .378 , respectively. 